Cosetta Seno

\title{
Ortese and the theory of difference in Il porto di Toledo
}

\begin{abstract}
Anna Maria Ortese is considered today as one of the greatest women writers of all times. This essay analyzes her contribution to Italian Women's Literature within the context of her relationship with two major waves of the Italian Feminist Movement: that of the 1970s, centered mainly on the idea of equality, and that of the 1980 s, centered on the idea of sexual difference. While writing her autobiography Il porto di Toledo Ortese became aware that the very experience of reality, centered on sexual difference, had to be reassessed and, consequently a new feminine language had to to be conceived. The contributions made by Ortese in Toledo proved to be invaluable in the creation of a new feminine language, distant from the Lacanian symbolic order and capable to express the experience of reality in a new and unique way.
\end{abstract}

\section{a. Ortese, the Italian Literary Canon and Gender Literature}

Anna Maria Ortese is today recognized as one of the greatest Italian women writers of the $20^{\text {th }}$ century. As her literary career progressed, she moved away from Italian Magic Realism and the Fantastic tradition in order to reach her own literary style, one that would allow her to describe the world around her through her own personal vision. In her short stories and novels she used fantasy not to escape reality but on the contrary, as a tool to enrich our perception of reality, enabling us to criticize it and change it.

Because of her experimentation with different literary modes and genres, Ortese has been traditionally considered an impossible author to classify within the Italian literary canon. As a result, her work has often been either praised as visionary or dismissed as unreliable, frequently at the same time. Throughout her career, Ortese has certainly tried to adapt her writing style to the demands of several different literary movements of the $20^{\text {th }}$ Century - which entailed a constantly changing relation in the representation of reality - but she could never bring herself to completely accept such demands. Therefore her initial neorealism was never mimetic in the traditional sense, her peculiar language never embraced elitism, as it would in the avant-garde, and her post-modernist writings would

The e-journal «altrelettere» is hosted at the URL: http://www.altrelettere.uzh.ch , in accordance with the Open Access Policy of the University of Zurich. Please cite this article as follows: Cosetta SENO, Ortese and the theory of difference in Il porto di Toledo, in «altrelettere», 31.12.2017, DOI: 10.5903/al_uzh-36.

(C) This article is licensed under a Creative Commons Attribution 2.5. Switzerland (CC BY-NC-ND 2.5). Please read the license terms on the website: http://creativecommons.org/licenses/by-nc-nd/2.5/ch/deed.en 
always have a strong component of social criticism. In other words, Ortese always had her own perceptive and sensitive way of interpreting reality, based on compassion and emotional participation. It is relevant in this context to remember what Adalgisa De Giorgio writes about women's writing and experimentalism:

Should women choose formal and linguistic experimentation, which is subversive, but potentially uncommunicative, or communicative representational modes, which perpetuate the literary as well as the social status quo? And is Realism inevitably conservative or reactionary, reproducing women's oppression and experimentalism automatically subversive and therefore liberating for women? (DE GIORGIO 2006, 97)

This is a challenging question, particularly in the case of Ortese. Can we really affirm that formal and linguistic experimentations have prevented her from effectively communicating what she had to say? Moreover, can we confidently assert that her constant resistance against pre-determined stylistic rules, her extraordinary imagination and her experimenting with many different literary genres, have forced her to give up on Realism? We don't think so. If we re-read some her works today, it is clear to understand how relevant they are in today's society. It is almost as if her imagination and visionary qualities would allow her to better understand the world she lived in and the capability to talk about it like very few realist writers could do.

Within this context and to offer further clarification of her extraordinary contribution to Italian Women's Literature: that of the 1970s, centered on the idea of equality and liberation, and the 1980 s centered on the idea of sexual difference. This essay demonstrates how Ortese's own emancipation, both in a literary and personal way, allowed her to overcome the ideological limitations of 1970 seminism and foresee a new form of feminist thought. ${ }^{1}$ This new form of feminism, which would become popular in France in the 1970s and in Italy in the 1980 s, would be no longer based solely on equality and liberation, but rather on exploring the differences between the two sexes. The very experience of reality centered on sexual difference had to be reassessed: consequently a new feminine language, quite different from the one proposed by the Lacanian symbolic order, had to be conceived. ${ }^{2}$ The contributions made by Ortese and her literature proved 
to be invaluable in the creation of this new language, one that would express a different and unique way of experiencing reality.

\section{b. The feminists and Toledo. An unsolved mystery.}

This is what Ortese wrote to Franz Haas in 1990:

Ma Toledo resta un imperdonabile e oscuro peccato letterario e morale per tutti. Credo che entri in questa condanna, l'ancestrale terrore di qualche cosa che la donna non deve esprimere: se la parità (interiore) con l'uomo e la sua non appartenenza al luogo comune, non so. Ma temo che Toledo fu proprio un romanzo trasgressivo per le stesse femministe: dichiararono infatti, nel ' 75 , che bisognava toglierlo dalle loro librerie. E lo tolsero. (Per le sinistre letterarie fu anche peggio. E per le destre un poco) (ROGNONI-HAAS 2016, 82-83).3

It is difficult to establish whether this comment represented one of the many fears that plagued Ortese's mind, or if it were something that actually happened. Her perception that her novel could be considered transgressive since it revealed some sort of dangerous femininity was probably accurate. On the other hand, most her books, for various reasons, had been cause of contention among literary critics. It is remarkable how Carlo Betocchi, long before any discussion on feminism had taken front stage, had sensed in 1938 that Ortese's writing «esprime e valorizza quel residuo di femminilità che rimane incontrollabile da parte dell'uomo»4 (BETOCCHI 1938, 446) and attributed precisely to this residual the uneasiness that Ortese's books caused in her critics and readers. 5

But then again, let's go back to the 1970s. Who were indeed the feminists who, according to Ortese, had her book removed from their bookstores? This remains some sort of mystery, since even Franz Haas ${ }^{6}$ can not explain whether Ortese was referring to a specific episode, or if she has simply seen her book disappear from the windows of Rome's Women's Bookstore located near Piazza Farnese, not far from where Ortese lived. It is possible that Ortese, embittered and offended by the sudden disappearance of her book, imagined some sort of conspiracy against Toledo. Such conspiracy, in Ortese's mind, would have been planned not only by the publishing house Rizzoli - of this she was convinced - but also by the feminists who requested that her book be removed from the windows of the 
Women's Bookstores. This is how she will remember those times much later, in her essay Dove il tempo è un altro:

Quando terminai questo libro, era il 1975. Avevo impiegato per farlo - tra una disperazione e l'altra - sei anni. Appena uscito, sparì. Non era leggibile. Chi non si fa leggere, non vende, e questa - chiusura immediata della vendita, anzi ritiro del libro da varie librerie - fu dunque la conclusione (ORTESE 1997, 90).7

Going beyond Ortese's fears and delusions, one thing is certain: when Toledo was published in 1975, very few copies were sold (around 8000 copies, according to Rizzoli) and very few reviews were published. ${ }^{8}$ If we consider that in the very same year and with the same publishing house, Oriana Fallaci sold 350,000 copies of Lettera a un bambino mai nato and Victoria Ronchey sold about 80,000 copies of Figlioli miei, marxisti immaginari, Ortese's disappointment is not surprising. Ortese felt distressed and foiled by Toledo's lack of success and meager sales, and not only for economical reasons. As far as the reviews were concerned, they were indeed very few and none of the reviewers was able to understand the originality and the revolutionary nature of Toledo especially in terms of gender literature. To offer a few example, Luce D'Eramo's review, (D’ERAMo 1976, 176-184) proposed an excellent linguistic analysis of Toledo but did not touch upon a theme that today appears essential to our understanding of the novel's complexity: Ortese's challenge to the patriarchal model of autobiography as well as that of Bildungsroman. Olga Lombardi's review also remains indifferent to the linguistic originality of the novel, and states that the most convincing part of Toledo is the author's use of her youthful short stories and poems (the famous rendiconti e ritmici) which she uses to reconstruct her early life. Lombardi writes:

Entro questa biografia visionaria, nella storia invenzione di un'infanzia reale e sognata si inseriscono le prove di «espressività» [...] queste liriche in cui è avvertibile l'eco di diverse suggestioni costituiscono il versante più valido del libro, quello in cui il linguaggio ritrova la sua naturale struttura e compagine. Tutto il romanzo è infatti impostato su un discorso fluente e dissipante che non si coagula in sintassi ma resta aperto e franto, spesso travolto, con clausole tronche e frequenti elisioni del verbo; nella ricerca del poetico il linguaggio si fa lezioso e artefatto, con costrutti infantili e alogici (LOMBARDI 1975, 410). ${ }^{9}$ 
Going back to Ortese's letter to Franz Haas we prefer not to believe in the conspiracy theory and we suspect that Toledo might indeed have been removed from the windows of the Women's Bookstores, but only because it did not sell enough copies. However, we must also wonder if Toledo, while being physically removed from the windows, was not also removed, at a subconscious level, from the minds of the women leading the Women's Bookstores. We wonder what would have happened if, instead of forgetting about it, the Women's Bookstores would have actively promoted Toledo with presentations and debates. It must be emphasized again how Ortese's book came out right in the middle of the 1970s, when feminism finally achieved a strong and intellectual pull and an unparalleled ability to influence the masses to a degree that it would never reach again at least in Italian society. In 1974 the divorce law was approved; in 1978 the abortion law was also approved, and finally in 1981 the codice Rocco - on the jurisdiction of honour crimes - was modified, and rape was finally recognized as a crime against the person and not against morality.

Among the 1970s feminists, this lack of curiosity and interest towards Ortese's book is particularly thought provoking, since Toledo is, above all, a female Bildungsroman, a novel of formation; however its originality lays in the fact that the young protagonist, Ortese herself, does not have access to the tools which would allow that very same formation to happen. That is why she has to go back and reconsider her own youthful writings, the famous rendiconti e ritmici, which she does not even dare to call "poetry" and "short stories" since she feels excluded by that same literary tradition she is trying to infiltrate. So why did the 1970 s feminists not embrace Toledo? It is possible to imagine that some of the philosophical questions posed by Ortese caught them by surprise or were misunderstood. In fact while the novel is based on the concept of inequality, Ortese goes far beyond the question of equality, rights and liberation, and confronts instead the much more complex problem of identity.

\section{c. Why not a feminist?}

During her lifetime, Anna Maria Ortese (1914-1998) never belonged to the feminist movement. Not only that, she was also not fond of it, and her relations 
with the feminists of her era (as we have seen in the case of Toledo) were difficult and often polemical.

Although Ortese's principles were often far more radical than those of the feminists, she always shied away from their practices and slogans. Her proud autonomy created a gap which, in time, became more and more difficult to bridge. Her reluctance to embrace a movement she seemed so naturally a part of is perplexing and at times mysterious, since Ortese's life was, in many ways, a monument to women's independence and equality. How can this incongruence be explained? Perhaps Ortese's learned diffidence can be, at least partially, rationalized by considering three factors: the times in which Ortese lived her formative years, her own independent personality and the Italian feminism that was part of the 1970 .

Born in 1914 in Rome, Ortese was raised in Mussolini's fascist Italy (19221943), an historical period when Italian Feminism - which had been rising in popularity at the end of the $19^{\text {th }}$ century ${ }^{10}$ - was damaged by the Duce's politics and practices. ${ }^{11}$ Although at first he seemed to be a supporter of women's independence, Mussolini ended up creating a series of policies which not only threatened women's independence but ended up accepting women's presence in society only as fascist wives and mothers of the Italian nation. Given the historical circumstances, it must have been hard for a young Anna Maria Ortese to develop some sort of feminist awareness at a time when everything around her appeared to emphasize a submissive and passive model of femininity. Although unprepared to be a feminist at the intellectual level, Ortese was in her life a natural feminist, resisting Mussolini's propaganda by rejecting the role of devout wife and prolific mother. She remained single all her life and supported herself through her profession of journalist and writer.

Ortese's debut in 1937 with Angelici dolori made her a celebrity in her own time, and raised the endless and unanswered question of where to place her in the canon. If, in the beginning, Massimo Bontempelli - the Italian intellectual who invented Italian Magic Realism - took her under his wing, it would have soon been seen that Ortese was too much of what Italian feminist scholar Rosi 
Braidotti would define as a «nomadic subject», ${ }^{12}$ to be confined within one literary movement no matter how popular it was. Ortese soon moved on and started exploring the literary world around her with its many different literary genres. Despite her undeniable talent, she often ended up as an unwelcome guest in any literary movement whose poetics would try to impose rigid rules on Ortese's writing.

It is well known what happened in 1953, when Ortese, by then part of Gruppo sud and therefore, at least in theory, following the dispassionate Neorealist dictate, wrote an unusual and hybrid reportage: Il mare non bagna Napoli. ${ }^{13}$ This book was destined to create turmoil for many years to come. What placed Ortese at the center stage of the Italian literary world was, this time, not only her harsh criticism of the Neapolitan leftist intellectuals who used to be her good friend, but also her writing style. What was supposed to be an impersonal and detached neorealist reportage, became in Ortese's book something completely different. Ortese's style conveyed a strong personal participation and an emotional closeness to the facts and the people described that was not contemplated by the strict dictates of the Neorealist poetics.

This famous episode in Ortese's professional life points out, once again, the importance of Ortese's artistically and ideologically independent personality. As we already mentioned, she was often a pioneer, exploring in her fiction themes and problems which would be seen as crucial many years later. Just to offer an example, L'Iguana, published in 1965 is now seen as a key text in the field of ecocriticism. ${ }^{14}$ However, her independent personality also caused her grief and misunderstanding. Because of her uniquely personal way to interpret reality, she could never quite fit in with any group that, by necessity, would create its own imposed rules and limitations. If critics would later consider a personal way of experiencing and interpreting reality to be an important factor in assessing women writers' production, it was not always so. The less homogenized point of view that women writers could offer - so important for a critical re-evaluation of historical times from a minority point of view - was initially devalued and degraded for the very same reasons. As Barbara Johnson would write in 1987: 
Not only personal experience tended to be excluded from the discourse of knowledge, but the real of the personal itself has been coded as female and devalued for that reason. (JOHNSON 1987, 43-44)

By the time feminism had gained popularity and power in Italy, Ortese had long struggled through the battle for equality and further liberation that Italian feminists were embracing in the late 1960s. As Serena Sapegno points out, it is precisely at the end of the 1960s that the concept of liberation becomes popular in Europe and in Italy in order to express the need of a deeper transformation:

Adottando questa nuova parola d'ordine, la liberazione, si vuole esprimere il desiderio di trasformazione più profonda [...] Con la liberazione infatti si vuole auspicare anche un'ampia modificazione della società e dei ruoli di genere, messi esplicitamente in discussione. (SAPEGNO 2011, 133) ${ }^{15}$

Ortese had long been aware of the necessity to go beyond equality and to question gender roles, and throughout her life and career she had constantly challenged them. Following are a few famous extracts from different interviews.

Dall'età di 17, 18 anni, mi sono sempre battuta [...] non avevo mestieri, non avevo denaro, né una famiglia che potesse servirmi da appoggio materiale. Ho potuto fare una sola cosa: scrivere. Non è stato facile. Per un uomo, essere uno scrittore, negli anni in cui ho iniziato io era un modo di vivere di tutto rispetto. Per una donna era diverso (SERENI 1993, 93). ${ }^{16}$

La condizione di donna se non ha reddito o non porta il nome del marito, ma solo del padre, è condizione oltraggiosa (VACCARI 1974, 3). ${ }^{17}$

In the 1970 Italian women experiment with Autocoscienza, a political practice coming from the United States where it was developed in the late 1960s in the form of Consciousness Rising Groups:

Il racconto di sé, che passa dall'una all'altra delle partecipanti secondo un filo di associazioni mentali che permette di individuare somiglianze e differenze, dà per la prima volta voce 'politica' alle vite personali e legittima un pensiero collettivo. [...] La Donna come nuovo soggetto collettivo nasce così attraverso una significativa inversione, quello spostamento nel privato che non costituisce un «ritorno a casa» ma al contrario un ribaltamento simbolico che dichiara la 'politicità' della dimensione del Personale [...] e la necessità conseguente di farne un'analisi per modificarlo (SAPEGNO 2011, 153). ${ }^{18}$

When Anna Maria Ortese starts writing her autobiography in 1969, however, she is going through a profound personal crisis as a writer. She feels deeply 
dissatisfied with her career and she has lost her artistic inspiration. While Italian feminists are trying to transform the woman subject into a political subject Ortese, on the contrary, is disappointed in politics and feels more and more distant from it. Here is what she writes:

Quando scrissi questo libro, a Milano quattordici anni fa, la città era già immersa nell'aria innaturale e infiammata della Contestazione. Non so se la cosa influì sulla scrittura di Toledo. In senso negativo, se questo avvenne. Il rumore, la violenza eterna della grande città dalla quale non potevo mai fuggire, si accrescevano di questo riverbero "politico". Odiavo il "politico" di tutti i tempi e in ogni sua espressione. [...] Credo che in realtà fosse il mondo a non piacermi più (ORTESE 1998, 551). ${ }^{19}$

In order to overcome depression and disappointment, Ortese decides to go back to the roots of her own vocation, to her childhood and to those famous rendiconti e ritmici which marked the beginning of her artistic career. She chooses to 'start from herself', she practices autocoscienza but not in the way the feminists are practicing it in order to find a collective female and political subject. Once again she resists and defies the boundaries of the group to delve into her personal journey. By doing so, she makes a discovery that brings her closer not to the feminists of her own times, but to the ones who are yet to come. Always a pioneer, she is once again shooting light years ahead into a different wave of feminism: beyond equality, beyond liberation, she realizes that her life experience was not only unfair and unequal; it simply was not real. It did not exist. Ortese's autobiography Il porto di Toledo published in 1975 is considered now to be one of the most important works in women's literary history because Ortese tried something nobody ever dared to do: she broke the bond between reality and fiction. Her autobiography is both. She defied the reader's expectations by openly breaking the «autobiographical pact» (LEJEUNE 1986) which had always marked any respectable autobiography. In order to write her authentic life story, Ortese seemed to say, she could only write a false autobiography. However contradictory this statement may seem, we can clarify it by analysing her novel through the lens of the Theory of Sexual Difference. 


\section{d. Ortese and Toledo. The story of an "unreal life" and the Theory of Difference.}

The Theory of Difference was born in France in the 1970s. ${ }^{20}$ Luce Irigaray was the scholar who first theorized it in 1974, in her Ph.D. dissertation, Speculum, the concept that women find their definition as human beings only as opposites of men. Women therefore are always thought of as objects of discourse and never as subjects. Irigaray was also the first scholar to conceive the necessity of a female genealogy and to recognize the existence of a maternal language based on a symbolic order different from the traditional Lacanian one. Her ideas, together with those of other French feminist scholars (such as Kristeva and Cixous) became very popular in Italy in the late 1970 s and early 1980 s and led to the creation of the feminist Academic collective group Diotima, based in Verona, which embraced the ideas of the French Theory of Difference offering multiple original contributions. This essay refers in particular to the work of Adriana Cavarero and Luisa Muraro which can help us better understand the articulations of Ortese's thought in her autobiography Il porto di Toledo.

I believe, in fact, that Ortese's feminism is most apparent not in her public declarations, but rather in her peculiar way of conceiving the world and reflecting upon it. These reflections, once transferred into her literary works, reveal an unquestionable closeness to the philosophical thought proposed by the Italian Theory of Difference. The famous opening lines of Toledo read:

Sono figlia di nessuno, nel senso che la società quando io nacqui non c'era o non c'era per tutti i figli dell'uomo. E nascendo senza società o bontà io stessa, in un certo senso non nacqui nemmeno, tutto ciò che vidi e seppi fu illusorio come i sogni della notte che all'alba svaniscono (ORTESE 1998, 23). ${ }^{21}$

And again, in 1985, when Toledo was republished, Ortese wrote in a note that introduced the novel:

C'era in me una grande negazione del reale (lo vedevo come inganno e fuga), e oggi questo reale era tutto. Inganno e fuga erano tutto (ORTESE 1998, 552). ${ }^{22}$

Just from these two examples, we can see the close contact between Ortese's ideas and one of the central questions posed by Cavarero, that is: How do we 
define reality? Cavarero, recognized as one of the most important Italian philosophers within the Theory of Difference, writes in Dire la nascita:

Il problema che intendo pormi è: che cosa sia il reale. Una lunga tradizione filosofica, a partire dal platonismo, mi ha insegnato che il reale non è l'ambito dei fatti "nudi e crudi" ma piuttosto l'ordine simbolico che il pensiero (il linguaggio, la cultura, il codice sociale) attribuisce al mondo. Com'è noto, questo ordine simbolico è di marchio patriarcale [...] Così se rimango fedele all'insegnamento della tradizione filosofica, il mio essere donna rischia di risultare di per sé un fatto nudo e crudo - un mero esistere senza significazione simbolica e perciò irreale (CAVARERO 1990, 93). ${ }^{23}$

As we have seen from the very first lines of Toledo, Ortese was always instinctively and acutely aware of her unreality. Ten years later, when Toledo was republished, she was still questioning the actual reliability of the so-called real. Given these premises we can see how she could very well conceive the narration of her own biography as something unreal. We can also see how the supposed unreality of the life of a woman was destined to become both a limitation and a challenge to her narrative.

In Toledo, Ortese ends up choosing to trespass the limits of the autobiographical pact in the traditionally conceived autobiography in order to reach a new narration made up of additions and changes, so as to give voice to the sexual difference of her own life story. Unknowingly and instinctively she is lining up with the future feminist philosophers of Difference, those who have fiercely contrasted the inevitable necessity on the women's side to find confirmation of their own existence within the system of patriarchal codes. Ortese embraces a whole new way of thinking and writing about her identity. Thanks to the category of 'birth' the Theory of Difference has been able to redefine the concept of 'real' itself, revealing therefore the existence of a maternal symbolic order which, according to Cavarero: «has given visibility to the unexpected (that is the woman) within the well established cultural codes» (CAVArero 1990, 93).

According to the Theory of Difference, the existence of every single human being finds new roots in the act of birth, which, paradoxically, is opposed to the patriarchal symbolic order as a real fact, «un fatto nudo e crudo» (CAVARERO 1990, 93). 
In Toledo, through a new symbolic order, Ortese cannot only create a new language, but she can also retrieve the memory necessary to reconstruct the story of her life. This thought process is mentioned in one of the following editions of Toledo, when Ortese explains what made her decide to write her false autobiography:

E pensai: dove sarà qualcosa di reale-reale, un continuo, come dicono I filosofi? E vidi che era la memoria. Mi impegnai dunque a scrivere un libro di memoria (ORTESE $1998,552) .{ }^{24}$

Therefore we see how in Ortese and in her autobiography, the theory and practice of Difference intersect with each other in the most fruitful way, so as to arrive at the comprehension of a reality that, in the light of the new symbolic order, uses memory as a key instrument of investigation. In this artistic process, Ortese reveals herself to be profoundly close, although always in her unique way, to the practice of «partire da sé » (MURARO 1996, 8) peculiar to the feminist movement of the late 1960 os and later re-discovered by the feminists in the 1980 s and $1990 \mathrm{os}$.

Muraro, another important philosopher within the Theory of Difference, wrote:

Torno così al tema del partire da sé come filosofia pratica. Il suo pregio principale [...] è che non ti fa trovare dove gli altri ti aspettano, senza che per questo tu debba isolarti in solitudine. Non è strano perché gli altri si aspettano di trovarti nel posto ovvio, quello che ti è stato assegnato o che loro prevedono in base a certi segni prevedibili, mentre il «partire da sè» ti situa di volta in volta nella traiettoria del tuo essere che cambia, si muove, cerca (MURARO 1996, 8). ${ }^{25}$

Muraro's words resonate not only with the creative process of Ortese's own autobiography but also - as we read in Toledo's preface - in the words destined to Anne Hurdle (to whom the novel is dedicated), a young counterfeiter who lived in England at the end of the Eighteenth century and who was sentenced to death:

Anne viveva in una miseria cieca, infinita. Quella era la sua parte di mondo [...]. Al processo non si difese mai. Sapeva di avere offeso orribilmente la Legge che la voleva nel buio, come suo luogo naturale. E non aveva voce per difendersi, stette sempre zitta (ORTESE 1998, 13). ${ }^{26}$

In giving back to Anne the memory of her own story as an anticipation of her own, Ortese decides to let Anne and herself out of the obvious dark place to which both seemed to be destined. Ortese feels compelled to restore justice for this 
young woman who has been robbed of her own life because of her crime and also her inability to defend herself. And justice can be made, not only by reviving her memory but also by making herself, the author of Toledo, responsible for Anne's same crime: being a counterfeiter.

If Anne had counterfeited money to escape poverty, Ortese has to counterfeit her own autobiography to make it become what real literature, according to Ortese, must always be: a crime; more specifically a crime made of «aggiunte e mutamenti» (ORTESE 1998, 14) to an otherwise unalterable reality. Only by doing so can Ortese try to reach the place where nobody expects to find her: transformed from an illiterate and poor young girl into an author whose work is worth reading. By 'starting with oneself' Ortese places herself within the trajectory of her own human being, which is constantly changing and evolving. Ortese writes:

Avevo dato il via a una falsa autobiografia, ma questo era il meno. Avevo soprattutto impiantato una discussione sul mutamento e le aggiunte (e questa era Anne). La vecchia natura delle cose non mi andava. Inventai dunque una me stessa che voleva un'aggiunta al mondo, che gridava contro la pianificazione ottimale della vita. Che vedeva nella normalità solo menzogna. [...] Toledo non è una storia vera, non è un'autobiografia, è rivolta, è «reato» davanti alla pianificazione umana, alla sola dimensione umana che ci è rimasta (ORTESE 1998, 14). ${ }^{27}$

It is well known that Ortese had declared: «Quella lingua - per esprimere quanto mi era caro - nel mondo di ciò che siamo non esiste» (Ortese 1998, 476).28

We want to remember it, because it is with Toledo that Ortese starts to deconstruct the patriarchal language and invent a new language that can be called maternal. Ortese's language does not limit itself to impartially recount the past, the so-called «fatti nudi e crudi» (CAVARERO 1990, 93), because she senses that, according to the dominant male-centered philosophical tradition, such plain facts would be then deemed unreal since they do not have a symbolic representation. She also does not try to acknowledge her female childhood within the expected representation provided by the patriarchal codes, and therefore allows multiple and overlapping identities of the main character (herself) to constantly rise and disappear in the novel. The newly minted language of Ortese in Toledo must be capable of invention in order to voice a «nuovo evento 
fantastico»(ORTESE 1998, 14): her life. Her original journal, her first short stories and her first poems then become the many mediating objects (in the sense fantastic theory attributes to it) and serve the purpose of confirming that the unreal life that she talks about was really her life.

We can see then how Toledo has really been transformed into what Ortese initially wanted: a crime based on counterfeiting reality. Through the perpetration of this crime Ortese can not only reinvent her life, but also, thanks to a new language, translate into words the memories of her childhood in Naples and her first experiences as a writer. The youthful rendiconti e ritmici have now transcended into something more than simple notes scribbled on her youthful diary: they are now an essential part of her life-long journey to become a literary author. 


\section{Notes}

1 For the development of the Italian feminist thought in the 1960s, 1970s and 1980s cfr. Maria Serena Sapegno (ed.) Identità e differenze. Introduzione agli studi delle donne e di genere, capp. 6, 7 and 8 (SAPEGNO 2011). Cfr. Also Paola Bono, Looking Back, Looking Forward: Looking at Italian Feminism (BONO 2000, 166-180). See also Franco Restaino and Adriana Cavarero (eds.) Le filosofie femministe (RESTAINO-CAVARERO 1999).

2 Cfr. Luce Irigaray Speculum. L'altra donna (IRIGARAY 2010). Cfr. Luisa Muraro L'ordine simbolico della madre (MURARO 1991).

3 Translation in English: but Toledo is and remains an unforgivable and obscure moral and literary sin for everybody. I think it has to do with the primitive fear of something that women are not supposed to express: if this is the equality (interior equality) with man and her not belonging to the same place, I really do not know. But I am afraid that Toledo really ended up being a transgressive novel even for the feminists: they declared, in fact, in 1975, that it had to be taken away from their bookstores and they did take it away. You can only imagine what the other ones did. (For the leftist intellectuals was even worse. Even for the conservatives, a little bit) (ROGNONI HAAS 2016, 82-83).

4 Translation in English: Ortese's writing expresses and increases in value that residual of femininity which remains uncontrollable by men (BETOCCHI 1983, 446).

5 Betocchi goes on: "L'uomo comune (vedi tutti noi) si trova a disagio al suo cospetto, agitato tra l'entusiasmo che suscita in lui l'avventuroso e il nuovo, e la repugnanza che insorge da tutta la sua educazione e quadratura spirituale» (BETOCCHI 1938, 446). Translation in English: The common man (that is all of us) does not feel at ease in front of this residual of femininity, and he struggles between the enthusiasm for all that is adventurous and new and the disgust, coming from all his education and intellectual formation.

6 I want to thank Franz Haas for answering to my e-mail and for sharing with me his opinion.

7 Translation in English: When I finished this book, it was 1975. It took me to finish it - in between moments of desperation - six years. As soon as it was published, it disappeared. It was not readable. And books that cannot be read cannot be sold, and this - immediate stop to the sales, more, immediate withdrawal from several bookstores - was the end of it (ORTESE 1997, 90).

8 On this particular issue, Franz Haas and Luca Clerici have a different opinion. Cfr. Franz Haas (ROGNONI-HAAS 2016, 177-184) and Luca Clerici (CLERICI 2002, 465).

9 Translation in English: Within this visionary biography, within the real story/invention of a childhood real and illusionary at the same time, the «expressivity» trials can be inserted [...] these lyrics, through which you can still hear the echo of various suggestions, are the most valid aspect of the book, the one in which the language finds its natural structure. The whole novel is in fact based on a fluid and dissipate discourse that cannot coagulate into syntaxes but remains open [...] while looking for the poetic the language becomes false, artificial, with childish and illogical constructions (LOMBARDI 1975, 410).

10 On this topic see Elena Brilli's «Fare le italiane» Condizione delle donne e movimenti femminili dall'Unità alla grande guerra (BRILli 2011, 47-75). For a recent study and a reevaluation of Mozzoni's work, see Sara Ceccarelli's Anna Maria Mozzoni. La vicenda di una donna che si è battuta per altre donne (CECCARELLI 2016).

11 On this topic and to understand the contradictions on Mussolini's politics towards women see Victoria De Grazia's How Fascism Ruled Italian Women (DE GRAZIA 1992).

12 Cfr. Rosi Braidotti's Nomadic Subjects. Embodiement and Sexual Difference in Contemporary Feminist Theory (BRAIDOTTI 1994).

13 For an analysis of Anna Maria Ortese's peculiar point of view and original style in Il mare non bagna Napoli, cfr. Storie di ordinaria agonia. I racconti napoletani di Anna Maria Ortese (BALDI 2003). See also Cristina Della Coletta's Scrittura come utopia. La lente scura di Anna Maria Ortese (Della ColetTA 1999) and Cosetta Seno's Il mare non bagna Napoli. Due diversi tipi di estraniamento (SENO 2002).

14 Cfr. Serenella Iovino's Il femminile trasversale nell'Iguana di Anna Maria Ortese in Ecologia letteraria. Una strategia di sopravvivenza (Iovino 2006, 73-87). 
15 Translation in English: By adopting this new keyword, liberation, women want to express the need of a deeper transformation [...]. With the word liberation in fact, women want to express the desire for a more profound renovation of society and gender roles, which are now openly challenged (SAPEGNO 2011, 133).

16 Translation in English: Since I was 17, 18 years old I always fought [...]I had no work skills, I had no money, I had no family who could support me. I knew how to do only one thing: write. It was not easy. For a man, when I started, to be a writer was a respectable way of living. For a woman it was different (SERENI 1993, 93).

17 Translation in English: Being a woman, if one does not have one's one source of income, or is not married, is a shameful condition (VACCARI 1974, 3).

18 Translation in English: The narration of every woman's own story, going back and forth among all the participants, finds, through mental associations, similarities and differences in all the different life experiences. It gives, for the first time a 'political' voice to the personal life of each single woman therefore legitimizing a collective thought. [...] The Woman, as a new collective Subject, is therefore born, through a meaningful inversion, by moving into the private sphere. But this moving into the private sphere does not signify a "going back home"; quite the contrary: it is a symbolic overturn which ends up declaring the political dimension of the Personal and the necessity to analyse it in order to modify it (SAPEGNO 2011, 153).

19 Translation in English: When I wrote this book, in Milan, fourteens years ago, the city had already plunged into the unnatural and ignited atmosphere of the student protest. I do not know if this affected the writing of Toledo in a negative way. The noise, the eternal violence of the big city, that I could never escape, affected me even worse when the political echo of currents event increased. I hated "politics" of all times and in every expression. (...) I think that maybe it was the world that I did not like anymore (ORTESE 1998, 551).

20 Before proceeding further, I would like to underline that the last part of this essay does not intend to analyse in depth the Theory of Difference, in all its different aspects and ramifications both in France and Italy. For an excellent summary of the French Theory of Difference cfr. Daniela Palmeri La teoria della differenza sessuale nasce in Francia (SAPEGNO 2011, 158-159). Cfr. also Sexual Textual Politics by Toril Moi, and in particular the chapters devoted to French Feminism (MoI 2002, 100-166). Cfr. also Franco Restaino and Adriana Cavarero Le filosofie femministe (RESTAINO-CAVARERO 1999) for an analysis of the Theory of Difference in France and its ramifications on the Italian Feminist thought. Cfr. also Graziella Parati and Rebecca West (ed.) Italian Feminist Theory and Practice. Equality and Sexual Difference (PARATI and WEST 2002).

21 Translation in English: I am nobody's daughter, meaning that when I was born society did not exist, or not for all human beings. And being born without a society and without goodness myself, I was, to e certain extent, not even born, and all that I saw and knew was illusionary just like night dreams, which vanish at dawn (ORTESE 1998, 23).

22 Translation in English: There was, in me, a great denial of reality (I used to see the 'real' as a form of deception and flight from one's responsibility), and today this real was everything. Therefore deception and flight were everything (ORTESE 1998, 552).

23 Translation in English: The question that I intend to ask myself is what is the so called real. A long philosophical tradition, starting from Platonism, has taught me that 'real' is not about what simply happens to us: the mere facts. The 'real' is rather the symbolic order that our thought (in the form of language, culture, social manners) attributes to the world. And, as we know, this symbolic order has its roots in the patriarchal world [...] Therefore if I remain faithful to the teaching of our philosophical tradition, my being a woman can become a simple fact, something that just happened to me, a mere existence without any symbolic representation and therefore unreal (CAVARERO 1990, 93).

24 Translation in English: And I thought: where can I find something that is truly real, a continuum, as the philosophers say? And so I realized that it was memory. So I committed myself to writing a book of memories (ORTESE 1998, 552).

25 Translation in English: I am therefore going back to the topic of starting from oneself as a form of practical philosophy. Its most important value [...] is that it does not let you be found where people expected you to be, but in such a way that you do not need to isolate yourself. This is 
not odd, because people expect to find you in the obvious place that has been assigned to you, or that they can predict, based on certain predictable signs, while the starting from oneself puts you from time to time always in a different place within the trajectory of your own self, which is changing, moving, searching (MURARO 1996, 8).

26 Translation in English: Anne used to live in a dreadful, endless poverty. That was her part of the world [...] At the trial she did not even try to defend herself. She knew that she had transgressed, because she had to obey a Law that wanted to keep her in the dark, as if it were her natural place to be. And she did not have the voice to defend herself she remained silent for the entire length of the trial (ORTESE 1998, 13).

27 Translation in English: I had started a false autobiography, but this was my smallest misdemeanour. More than everything else, I had started a discussion on change and additions (and this was Anne). The old way of doing things did not suit me, and so I reinvented myself as somebody who wanted to change the world who was screaming against the optimal planning of human life. I reinvented myself as someone who saw all the lying behind the so-called ordinary life [...] Toledo is not a true story, it is not even a true autobiography. Toledo is an insurrection, Toledo is a violation against the planning of our human life, which, by the way, is the only human dimension we have left (ORTESE 1998, 14).

28 Translation in English: That language - to express what was dear to me - in this world of ours, does not exist (ORTESE 1998, 476).

\section{Bibliography}

BALDI 2003

Andrea BALDI, Storie di ordinaria agonia: I racconti napoletani di Anna Maria Ortese, in «Narrativa», 24 (2003), pp. 55-83.

\section{BETOCCHI 1938}

Carlo BETOCCHI, Scrittici italiane, in «Il Frontespizio», 7 (1938), p. 446.

\section{BONO 2000}

Paola BoNO, Looking Back, Looking Forward: Looking at Italian Feminism(s), in Feminisms and Women's Movements in Contemporary Europe, Eds. Bull, Diamond, Marsch, New York, St Martin's Press, 2000, pp. 166-180.

\section{BRAIDOTTI 1994}

Rosy BraidotTI, Nomadic Subjects: Embodiement and Sexual Difference in Contemporary Feminist Theory, New York, Columbia University Press, 1994.

\section{BRILLI 2011}

Elisa BRILLI, "Fare le italiane». Condizione delle donne e dei movimenti femminili dall'Unità alla Grande guerra, in Identità e differenze. Introduzione agli studi di donne e di genere, ed. Maria Serena Sapegno, Milano, Mondadori, 2011, pp. 47-75. 


\section{CAVARERO 1990}

Adriana CAVARero, Dire la nascita, in Mettere al mondo il mondo ed. Diotima, Milano, La Tartaruga, 1990, pp. 93-121.

CECCARELLI 2016

Sara CeCCARelli, Anna Maria Mozzoni: La vicenda di una donna che si ̀̀ battuta per altre donne, Rimini, Panozzo Editore, 2016.

CLERICI 2002

Luca Clerici, Apparizione e visione. Vita e opera di Anna Maria Ortese, Milano, Mondadori, 2002.

D'ERAMO 1976

Luce D'ERAMO, L'Ortese a Toledo in «Nuovi argomenti», 49 (1976), pp. 176-184.

DE GIORGIO 2006

Adalgisa De Giongio, From Little Girls to Bad Girls. Women's Writing and Experimentalism in the 1970 s and 1990 s in Speaking Out and Silencing: Culture, Society and Politics in Italy in the 1970s, Eds. Cento-Bull, De Giorgio, London, Legenda, 2006, pp. 95-115.

DE GRAZIA 1993

Victoria DE GRAZIA, How Fascism Ruled Italian Women: Italy 1922-1945, Berkeley, University of California Press, 1993.

DELla COLETTA 1999

Cristina Della ColeTta, Scrittura come utopia: La lente scura di Anna Maria Ortese, in «Italica», 76 (1999), pp. 338-371.

IOVINO 2006

Serenella IOVINO, Il femminile trasversale nell'Iguana di Anna Maria Ortese in Ecologia letteraria. Una strategia di sopravvivenza, Milano, Edizioni Ambiente, 2006, pp. 73-87.

IRIGARAY 2010

Luce IRIGARAY, Speculum, L'altra donna, ed. Luisa Muraro, Milano, Feltrinelli, 2010.

LEJEUNE 1986

Philip LEJEUnE, Il patto autobiografico, Bologna, Il Mulino, 1986.

LOMBARDI 1975

Olga LOMBARDI, Il porto di Toledo in «Nuova Antologia», 2095 (1975), pp. 409411.

JOHNSON 1987

Barbara Johnson, Deconstruction, Feminism and Pedagogy in A World of Difference, Baltimore, Johns Hopkins University Press, 1987, pp. 42-49. 
MOI 2002

Toril MoI, French Feminist Theory in Sexual Textual Politics. Feminist Literary Theory, New York, Routledge, pp. 100-166.

MURARO 1991

Luisa MURARO, L’ordine simbolico della madre, Milano, Editori Riuniti, 1991.

MURARO 1996

Luisa Muraro, Partire da sé e non farsi trovare, in La sapienza di partire da sé, ed. Diotima, Napoli, Liguori, 1996, pp. 5-23.

ORTESE 1997

Anna Maria ORTESE, Corpo celeste, Milano, Adelphi, 1997.

Ortese 1998

Anna Maria ORTESE, Il porto di Toledo, Milano, Adelphi, 1998.

PALMERI 2011

Daniela PALMERI, La teoria della differenze sessuale nasce in Francia in Identità e differenze. Introduzione agli studi di donne e di genere, ed. Maria Serena Sapegno, Milano, Mondadori, 2011, pp. 158-162.

PARATI-WEST 2002

Graziella PARATI, Rebecca WEST Eds., Italian Feminist Theory and Practice: Equality and Sexual Difference, Madison, Farleigh Dickinson University Press, 2002.

\section{RESTAINO-CAVARERO 1999}

Franco RestAINO, Adriana CAVARERo eds., Le filosofie femministe, Torino, Paravia, 1999.

ROGNONI-HAAS 2016

Francesco Rognoni, Franz HaAs eds., Anna Maria Ortese. Possibilmente il più innocente. Lettere a Franz Haas (1990-1998), Mergozzo, Diego Dejaco Editore, 2016.

SAPEGNO 2011

Maria Serena SAPEGNO ed., Identità e differenze. Introduzione agli studi di donne e di genere, Milano, Mondadori, 2011.

SENO 2002

Cosetta SENo, Anna Maria Ortese. Il mare non bagna Napoli: Due diversi tipi di estraniamento in «Rassegna Europea della Letteratura Italiana», 20 (2002), pp. 131-143.

SERENI 1993

Silvia SERENI, Storia straordinaria di un best seller e della sua incredibile autrice in «Epoca», 27 luglio (1993), pp. 91-93. 
VACCARI 1974

Luigi VACCARI, L'odore della miseria in «Il Messaggero», 19 giugno (1974), p. 3. 